\title{
Pengaruh Keunggulan Produk Pembiayaan Murabahah, Rahn Dan Penerapan Nilai-Nilai Islam Dengan Kualitas Pelayanan Terhadap Kepuasan Nasabah Pada PT BPR Syariah Lantabur Tebuireng Kantor Cabang Gresik
}

\author{
Guffron Abdul Azis; Mukhammad Roni; Taufiq Anshori \\ Institut Pesantren KH. Abdul Chalim Mojokerto, Indonesia \\ azisgufrony@gmail.com; roniwijayam@gmail.com; \\ taufiq86anshori@gmail.com
}

\begin{abstract}
The objectives of this research were to find the influence of murabahah, rahn financing product superiority and the application of Islamic values with quality of service to customer satisfaction in Islamic banks (PT BPR Syariah Lantabur Tebuireng Cabang Gresik). The approach of this research was quantitative using primary data. The sample in this research were customers of PT BPR Syariah Lantabur Tebuireng Cabang Gresik. With the sampling technique using nonprobability sampling, so the authors get a total sample of 75 respondents. Analysis of the data in this research using Smart PLS 2.0 analysis tools. The results showed that Murabahah Financing a significant positive effect on Service Quality. Rahn had a significant positive effect on service quality. Islamic values had a positive and not significant effect on service quality. Service Quality had a significant positive effect on Customer Satisfaction. Murabahah Financing had no significant negative effect on Customer Satisfaction. Rahn had a significant positive significant effect on Customer Satisfaction. Islamic values had an insignificant negative effect on customer satisfaction. From the results of the path test, intervening variables it was service quality proven to be able to mediate the relationship between, Murabahah Financing, Rahn and Islamic Values on customer satisfaction of PT BPR Syariah Lantabur Tebuireng Cabang Gresik.
\end{abstract}

Keywords: Murabahah, Rahn, Islamic Values, Service Quality, Customer Satisfaction.

\section{Pendahuluan}

Perbankan syariah mempunyai posisi yang utama dalam aktivitas perekonomian masyarakat. Banyak produk perbankan syariah yang dapat diharapkan bisa memajukan perekonomi dilandasi oleh syariat Islam. Kegiatan perekonomi tidak lepas pada prinsip Islam yaitu, beriman kepada Allah bahkan menjadi pengawas untuk pemakai ekonomi. Dengan adanya regulasi yang berlandaskan hukum pada institusi keuangan syariah membuat semakin kuat 
perbankan syariah yang ada di Indonesia. Perkembangan UU perbankan dari Undang-undang No. 7 Tahun 1992, dan dikuatkan oleh PP No. 72 Tahun 1992 dan UU No. 10 Tahun 1998, serta Undang-undang Republik Indonesia No. 21 tahun 2008 tentang Perbankan Syariah seperti memperoleh izin untuk membuka usaha di Indonesia. Melalui surat keputusan Direksi Bank Indonesia No. 32/34/KEP/DIR tanggal 12 Mei 1999 aturan mainnya ditetapkan oleh pemerintah ${ }^{1}$.

Bank Syariah harus mematuhi prinsip syariah yang dibuat oleh Dewan Pengawas Syariah dan Majelis Ulama Indonesia yang telah dituliskan di Peraturan Bank Indonesia Pasal 24 ayat (1) dan ayat (2) huruf a dan Pasal 25 huruf a UndangUndang No. 21 Tahun 2008 tentang Perbankan Syariah yang dengan teguh mengatakann bahwa, bank syariah dilarang menjalankan aktivitas bisnis yang keluar dari prinsip syariah. ${ }^{2}$

Perjanjian yang disusun pihak bank dan konsumen tidak boleh mengandung ketentuan yang berbeda dengan hukum syariah. Sesuai dengan norma, seperti tercantum pada KUHP, persetujuan tidak boleh berbeda dengan UU. Jika suatu persetujuan atau ketentuan tiba-tiba batal maka kesepakatan tidak sah. ${ }^{3}$

Prinsip syariah harus selalu ada dalam aktivitas yang dilakukan bank syariah yang ada di Indonesia. Prinsip syariah yang berdasarkan sumber-sumber hukum Islam terdiri dari sumber hukum primer yaitu, Al-Qur'an dan Al-Hadits dan sumber hukum sekunder yaitu, ijma' (konsensus para ulama), qiyas (penalaran/reasoning secara analogis) dan ijtihad (penalaran hukum secara mandiri). ${ }^{4}$ Berdasarkan

\footnotetext{
${ }^{1}$ M. Syafi'i Antonio, "Bank Syariah Analisis kekuatan, Kelemahan, peluang dan Ancaman”, cet. III. (Yogyakarta: Ekonisia, 2004), 61

${ }^{2}$ Pasal 24 ayat (1) dan ayat (2) huruf a dan Pasal 25 huruf a Undang-Undang No. 21 Tahun 2008 tentang Perbankan Syariah. 2018

${ }^{3}$ Sutan Remy Sjahdeini, Perbankan Syariah, Produk-produk dan Aspek-aspek Hukumnya, (Jakarta: Kencana Prenada Media Group, 2014), 127.

4 Thariq Ashraf, "Sharia-complaint Investing: Concept and Opportunities", http://www.csri.orgnz/document/tashraf, diakses tanggal 5 April 2019.
} 
hukum perjanjian Islam, Nilai-nilai Islam yang harus di implementasikan pada kegiatan perbankan syariah ialah, al-hurriyah (kebebasan), al-musawah (persamaan atau kesetaraan), al-'adalah (keadilan), ash-shidq (kebenaran dan kejujuran), al-ridha (kerelaan), al-kitabah (tertulis).

Menurut Al Gazali, uang memiliki peran penting dalam kegiatan perekonomian. Uang merupakan salah satu nikmat Allah SWT dan penopang kehidupan dunia. Karena itu uang harus dimanfaatkan sesuai dengan ketentuan syara'. Dalam Ihya' Ulum al-Din, Al Gazali menyatakan bahwa salah satu nikmat allah adalah telah diciptakannya dinar dan dirham sehingga dengan keduanya tegakllah dunia. Dinar dan dirham adalah benda mati yang pada hakekatnya tidak memiliki manfaat. Akan tetapi manusia membutuhkannya agar dapat mempunyai barang-barang, makanan, pakaian dan semua kebutuhan lainnya. Lebih lanjut ia juga menyatakan bahwa dinar dan dirham merupakan perantara terhadap sesuatu yang di inginkan. Didalam dinar dan dirham tidak ada manfaat manakala tidak ada keinginan terhadap sesuatu. ${ }^{5}$

Ketika aktivitas perbankan syraiah terdapat pengaplikasian nilai-nilai Islam di saat pihak bank syariah dengan nasabah membuat akad atau perjanjian. Pengaplikasian nilai-nilai islam yang baik dan benar akan akan membuat perbankan syariah menjadi lebih maju. Bagi setiap bank Syariah perlu adanya nilai-nilai Islam yang diterapkan sehingga memunculkan keyakinan masyarakat agar dapat menyimpankan uangnya dan menggunakan produk pembiayaan pada perbankan syariah. Semakin banyak masyarakat menggunakan pembiayaan maupun menemptakan dananya pada bank syariah, melihatkan bahwa masyarakat sudah menjadi nasabah yang loyal pada bank syariah.

Kepuasan nasabah merupakan sebuah ekspresi nasabah dan prilaku pembelian $^{6}$. Loyalitas yang dimiliki nasabah tidak luput dari kepuasan nasabah

\footnotetext{
5 Joko Hadi Purnomo, "Uang dan Moneter dalam Sistem Keuangan Islam". Journal of Sharia Economics. 1(2). 2019. 80-100.

${ }^{6}$ Lupiyoadi Rambat, "Manajemen Pemasaran Jasa”, (Jakarta: Salemba Empat, 2013), 232
} 
terhadap produk dan kualitas layanan yang telah dikasih oleh bank syariah kepada nasabah. Seehingga membuat pelanggan membeli produk pada bank tersebut. ${ }^{78}$

PT BPR Syariah Lantabur Tebuireng Kantor Cabang Gresik merupakan sebagian dari institusi keuangan syariah yang di Indonesia dan bank yang berhasil mendapatkan kepercayaan masyarakat. Selain itu, yang perlu di waspadai dalam meningkatkan produk pada PT BPR Syariah Lantabur Tebuireng Kantor Cabang Gresik ini dengan terus meningkatkan talisilaturahmi dengan nasabah yang telah terjalin. Dengn demikian memberikan dampak positif untuk perkembangan PT BPR Syariah Lantabur Tebuireng Kantor Cabang Gresik itu sendiri. Program yang harus dikerjakan terhadap PT BPR Syariah Lantabur Tebuireng Kantor Cabang Gresik untuk meningkatkan kepuasan nasabah itu dengan cara menerapkan kualitas pelayanan yang sangat efektif dengan model survey pada nasabah PT BPR Syariah Lantabur Tebuireng Kantor Cabang Gresik dalam menangkap tingkat kepuasan nasabahnya.

Kualitas pelayanan merupakan salah satu faktor yang mempengaruhi kepuasan nasabah dan yang menentukan kepuasan nasabah dalam suatu perusahaan. Kualitas pelayanan sebagai pengikat loyalitas nasabah di bidang perbankan syariah ${ }^{9}$. Penelitian yang telah dilakukan oleh pihak perusahaan maupun pihak luar banyak yang dijadikan sebagai pengukur dan penialaian kualitas pelayanan.

\footnotetext{
${ }^{7}$ Nik Haryanti dan Diyanus Abdul Baqi. "Strategi Service Quality Sebagai Media dalam Menciptakan Kepuasan dan Loyalitas Pelanggan". Journal of Sharia Economics. 1(2). 2019, 101128

${ }^{8}$ Nur Azizah, Joko Hadi Purnomo, Niswatin Nurul Hidayati. "Efektivitas Strategi Pemasaran Produk Tabungan Haji Dalam Meningkatkan Keunggulan Kompetitif di BRI Syariah Kantor Cabang Pembantu Bojonegoro". MIYAH: Jurnal Studi Islam. 16(1). 2020, 135-161.

9 J. Supranto. "Pengukuran Tingkat Kepuasan Pelanggan Untuk Menaikkan Pangsa Pasar". cet. III, Jakarta: Rineka Cipta, 2006, hal. 237
} 
Kepuasan nasabah ialah serangkaian program yang dimiliki PT BPR Syariah Lantabur Tebuireng Kantor Cabang Gresik. Untuk mencapai keunggulan bersaing dengan perbankan syariah yang lainnya PT BPR Syariah Lantabur Tebuireng Kantor Cabang Gresik menjadikan pemimpin pasar sebagai tujuan dalam mencapai kepuasan nasabah. Kepuasan nasabah bank syariah tidak terlepas dari kualitas pelayanan dan produk yang dikasihkan bank syariah kepada para pelanggannya. Akan tetapi yang membedakan bank syariah tersebut terdapat pada keunggulan produk yang mereka miliki.

Bank syariah harus paham dalam memuaskan keinginan para nasabahnya dengan menggunakan pelayanan prima supaya dapat bersaing dengan sehat. Sebelum bank syariah dapat memenuhi keinginan para nasabahnya, bank syariah harus berusaha sekeras mungkin dalam menyampaikan penjelasan yang bagus mengenai produk yang telah mereka promosikan terhadap nasabah dalam meningkatkan dan membuatkan keunggulan yang kompetitif.

Terdapat penelitian serupa yang telah dilaksanakan sebelumnya, misalnya penelitian oleh Muctharom" ${ }^{10}$ dengan judul "Pengaruh Kualitas Produk Murabahanm Harga, dan Kualitas Pelayanan Terhadap Kepuasan Nasabah di Baitul Maal Wat Tamwil Nurul Ummah Ngasem Bojonegoro", dimana penelitian ini menyimpulkan bahwa 1) Dalam uji t kualitas produk murabahah ada pengaruh yang signifikan terhadap kepuasan nasabah di KJKS BMT NU Ngasem-Bojonegoro dan hasil hipotesis penelitian telah teruji; 2) Dalam uji t Variabel tidak ada pengaruh yang signifikan terhadap kepuasan nasabah di KJKS BMT NU NgasemBojonegoro dan hasil hipotesis penelitian telah teruji; 3) Dalam uji t kualitas pelayanan tidak ada pengaruh yang signifikan terhadap kepuasan nasabah di KJKS BMT NU Ngasem-Bojonegoro dan hasil hipotesis penelitian telah teruji; 4) Dalam uji F, menggambarkan bahwa kualitas produk murabahah, harga dan kualitas pelayanan tidak ada dampak pengaruh terhadap kepuasan nasabah di KJKS BMT

\footnotetext{
${ }^{10}$ Moch Zaenal Azis Muctharom. "Pengaruh Kualitas Produk Murabahah, Harga, dan Kualitas Pelayanan Terhadap Kepuasan Nasabah di Baitul Maal Wat Tamwil Nurul Ummah Ngasem Bojonegoro". Journal of Sharia Economics. 1(1). 2019, 41-54
} 
Nurul Ummah Ngasem - Bojonegoro dan hasil hipotesis penelitian telah teruji; 5) Berdasarkan hasil di atas maka diketahui bahwa variabel yang paling dominan berdampak terhadap kepuasan nasabah adalah kualitas produk murabahah Karena variabel kualitas produk murabahah mempunyai nilai $F_{h i t u n g}$ lebih besar dari variabel harga dan variabel kualitas pelayanan dan hasil hipotesis penelitian telah teruji. Di samping itu, terdapat pula penelitian yang dilakukan oleh Ni'mah, dkk., yang meneliti di Bank Syariah Mandiri KCP Tuban. ${ }^{11}$, serta Mar'ah, dkk., di BMT Usaha Artha Sejahtera Bojonegoro. ${ }^{12}$

Berdasarkan latar belakang yang telah diuraikan di atas tujuan dalam penelitian ini adalah sebagai berikut: 1) Untuk mengetahui keunggulan produk Pembiayaan Murabahah berpengaruh signifikan terhadap kualitas pelayanan; 2) Untuk mengetahui keunggulan produk Rahn berpengaruh signifiakan terhadap kualitas pelayanan; 3) Untuk mengetahui penerapan nilai-nilai Islam berpengaruh signifikan terhadap kualitas pelayanan; 4) Untuk mengetahui kualitas pelayanan berpengaruh signifikan terhadap kepuasan nasabah; 5) Untuk mengetahui keunggulan produk Pembiayaan Murabahah berpengaruh signifikan terhadap kepuasan nasabah; 6) Untuk mengetahui keunggulan produk Rahn berpengaruh signifikan terhadap kepuasan nasabah; 7) Untuk mengetahui penerapan nilai-niali Islam berpengaruh signifikan terhadap kepuasan nasabah.

\section{Metode Penelitian}

Penelitian ini menggunakan metode kuantitatif dengan melakukan analisis data menggunakan statistik. Menurut Sugiyono penelitian kuantitatif merupakan suatu investigasi yang lebih dominan yang berbentuk angka untuk dianalisis

\footnotetext{
${ }^{11}$ Karomatun Ni'mah, Joko Hadi Purnomo, Niswatin Nurul Hidayati. "Pengaruh Marketing, Nilai Taksiran, Dan Biaya Titip Pada Gadai Emas Terhadap Minat Nasabah Menggunakan Fasilitas Gadai Emas di PT. Bank Syariah Mandiri KCP Tuban". LISAN AL-HAL: Jurnal Pengembangan Pemikiran dan Kebudayaan. 14(1). 2020, 1-38.

12 Ana Kholifatul Mar'ah, Joko Hadi Purnomo, Niswatin Nurul Hidayati. "Effect of Mudharabah Financing Toward Seller Members' Income at BMT Usaha Artha Sejahtera Bojonegoro. SHAHIH: Journal of Islamicate Multidisciplinary. 5(1). 2020, 15-36.
} 
dengan tujuan mendapatkan jawaban dari rumusan masalah dan hipotesis yang ditetapkan. ${ }^{13}$ Sampel penelitian adalah nasabah PT BPR Syariah Lantabur Tebuireng Kantor Cabang Gresik.

Jenis data yang digunakan dalam penelitian ini adalah data primer, yaitu data yang didapat dari sumber pertama baik individu atau perseorangan. Data diperoleh langsung dari responden melalui hasil pengisian kuesioner. Sumber data primer yang digunakan dalam penelitian ini adalah data terkait persepsi responden mengenai Pembiayaan Murabahah, Rahn, nilai-nilai Islam, kualitas pelayanan dan kepuasan nasabah dan data sekunder, yaitu sumber data yang diperoleh dari beberapa buku, jurnal, media social, website dan sumber informasi lain yang masih relevan dengan penelitian yang akan dilakukan.

Analisis data yang digunakan dalam penelitian ini menggunakan Partial Least Square (PLS). PLS merupakan suatu alat analisis data yang digunakan dalam penelitian yang memiliki sedikit sampel. Softwere yang digunakan PLS adalah SmartPLS, WordPLS, PLSgraph dan Visual Graph. PLS memiliki suatu kelebihan dibandingkan SEM dimana PLS mampu mengatasi setiap varibel yang memiliki banyak indikator dan dapat digunakan pada penelitian yang memiliki sedikit sampel.

Gambar 1

Kerangka Pemikiran

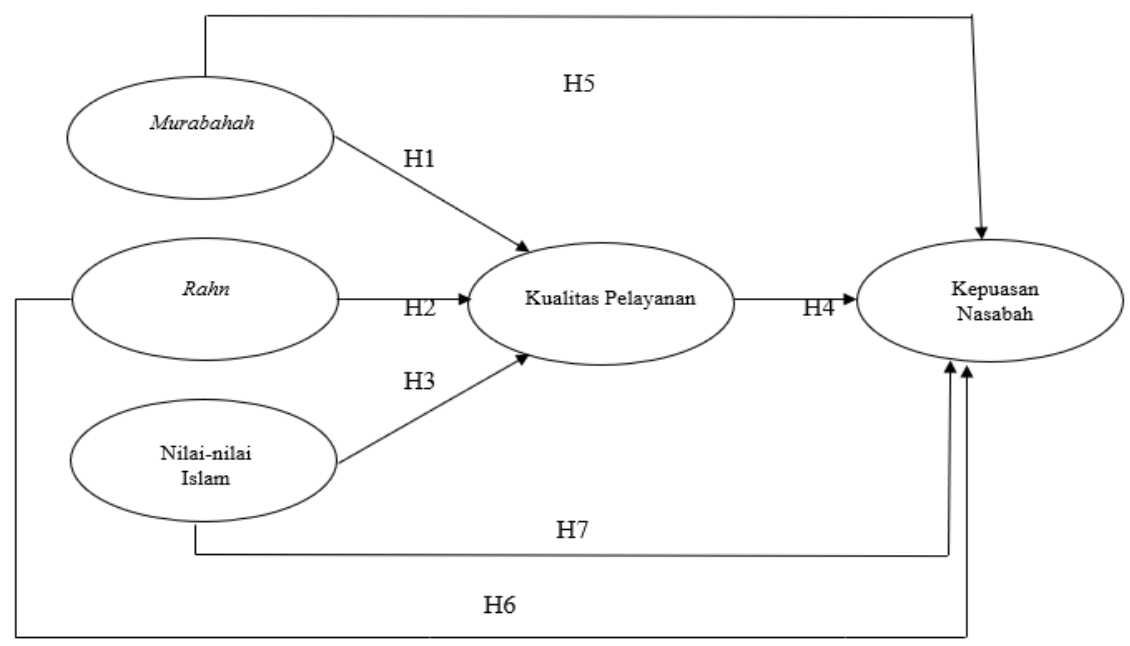

${ }^{13}$ Sugiyono, Metode Penelitian Kuantitatif, Kualitatif dan R\&D, (Bandung: Alfabeta, CV, 2016), 14. 
Keterangan gambar:

1. Murabahah, Rahn dan Penerapan nilai-nilai Islam dijadikan sebagai variabel independen.

2. Kualitas Pelayanan pada penelitian ini dijadikan sebagai variabel intervening.

3. Kepuasan Nasabh pada penelitian ini dijadikan sebagai variabel dependen.

Kerangka pemikiran yang telah dituangkan pada gambar di atas melahirkan suatu rancangan uji hipotesis dalam penelitian ini sebagai berikut:

$\mathrm{H}_{1=}$ Produk Murabahah berpengaruh signifikan terhadap kualitas pelayanan PT BPR Syariah Lantabur Tebuireng Kantor Cabang Gresik.

$\mathrm{H}_{2=}$ Produk Rahn berpengaruh signifikan terhadap kualitas pelayanan PT BPR Syariah Lantabur Tebuireng Kantor Cabang Gresik.

$\mathrm{H}_{3}=$ Penerepan Nilai Islam berpengaruh signifikan terhadap kualitas pelayanan PT BPR Syariah Lantabur Tebuireng Kantor Cabang Gresik.

$\mathrm{H}_{4}=$ Kualitas pelayanan berpengaruh signifikan terhadap kepuasan nasabah PT BPR Syariah Lantabur Tebuireng Kantor Cabang Gresik.

$\mathrm{H}_{5}=$ Produk Murabahah berpengaruh signifikan terhadap kepuasan nasabah PT BPR Syariah Lantabur Tebuireng Kantor Cabang Gresik.

$\mathrm{H}_{6}=$ Produk Rahn berpengaruh signifikan terhadap kepuasan nasabah PT BPR Syariah Lantabur Tebuireng Kantor Cabang Gresik.

$\mathrm{H}_{7}=$ Penerepan Nilai Islam berpengaruh signifikan terhadap kepuasan nasabah PT BPR Syariah Lantabur Tebuireng Kantor Cabang Gresik 


\section{Hasil dan Diskusi}

Tabel 4.1

Bootstropping

\begin{tabular}{|l|l|l|l|l|l|}
\hline & $\begin{array}{l}\text { Original } \\
\text { Sample (O) }\end{array}$ & $\begin{array}{l}\text { Sample } \\
\text { Mean (M) }\end{array}$ & $\begin{array}{l}\text { Standard } \\
\text { Deviation } \\
(\text { STDEV })\end{array}$ & $\begin{array}{l}\text { Standard } \\
\text { Error } \\
(\text { STERR })\end{array}$ & $\begin{array}{l}\text { T Statistics } \\
(\mid \text { O/STERR })\end{array}$ \\
\hline $\begin{array}{l}\text { Kualitas Pelayanan - } \\
\text { Kepuasan Nasabah }\end{array}$ & 0.338881 & 0.346066 & 0.126223 & 0.126223 & 2.684771 \\
\hline $\begin{array}{l}\text { Murabahah -> } \\
\text { Kepuasan Nasabah }\end{array}$ & -0.020375 & 0.02956 & 0.172737 & 0.172737 & 0.117953 \\
\hline $\begin{array}{l}\text { Murabahah } \\
\text { Kualitas Pelayanan }\end{array}$ & 0.381702 & 0.397523 & 0.111684 & 0.111684 & 3.417712 \\
\hline $\begin{array}{l}\text { Nilai-Nilai Islam -> } \\
\text { Kepuasan Nasabah }\end{array}$ & -0.237006 & -0.225128 & 0.177613 & 0.177613 & 1.334395 \\
\hline $\begin{array}{l}\text { Nilai-Nilai Islam -> } \\
\text { Kualitas Pelayanan }\end{array}$ & 0.146768 & 0.141504 & 0.089204 & 0.089204 & 1.645305 \\
\hline $\begin{array}{l}\text { Rahn -> Kepuasan } \\
\text { Nasabah }\end{array}$ & 0.436657 & 0.419676 & 0.145365 & 0.145365 & 3.003863 \\
\hline $\begin{array}{l}\text { Rahn -> Kualitas } \\
\text { Pelayanan }\end{array}$ & 0.291579 & 0.283451 & 0.109398 & 0.109398 & 2.665313 \\
\hline
\end{tabular}

Sumber: pengolahan data PLS 2.0, 2020

Dari tabel 4.13 diatas memperlihatkan hasil yang menunjukkan pengaruh langsung antara variabel. Disebut pengaruh langsung apabila nilai $\mathrm{T}$ Statistic $>\mathrm{T}$ tabel $(1,96)$ :

\section{Pengaruh Pembiayaan Murabahah terhadap Kualitas Pelayanan}

Berdasarkan hasil uji hipotesis, dapat dibuktikan bahwa adanya pengaruh antara Pembiayaan Murabahah terhadap Kualitas Pelayanan. Pengaruh yang dihasilkan adalah positif yang apabila penerapan Murabahah dalam BPR Syariah Lantabur Tebuireng Cabang Gresik semakin baik maka akan berdampak pada peningkatan Kualitas Pelayanan pada BPR Syariah Lantabur Tebuireng Cabang Gresik. 
Selain itu dapat dilihat dari nilai statistik dan Original Sample (O). Bahwa nilai t-statistik yang menunjukan nilai sebesar 3.417712 lebih besar dari 1,96 dan Original Sample $(O)$ 0.381702. Dengan demikian dapat disimpulkan bahwa Pembiayaan Murabahah pengaruh positif yang signifikan terhadap Kualitas Pelayanan. Dalam penelitian ini peneliti belum menemukan penelitian terdahulu yang membahas masalah yang sama sehingga mampu dijadikan keterbaruan pada penelitian.

\section{Pengaruh Rahn terhadap Kualitas Pelayanan}

Berdasarkan hasil uji hipotesis, dapat dibuktikan bahwa adanya pengaruh antara penerapan Rahn terhadap Kualitas Pelayanan. Pengaruh yang dihasilkan adalah positif yang apabila penerapan Rahn dalam bank syariah semakin baik maka akan berdampak pada peningkatan Kualitas Pelayanan BPR Syariah Lantabur Tebuireng Cabang Gresik

Selain itu dapat dilihat dari nilai statistik dan Original Smaple $(O)$. Bahwa nilai t-statistik yang menunjukan nilai sebesar 2.665313 lebih besar dari 1,96 dan Original Sampel (O) 0.291579. Dengan demikian dapat disimpulkan bahwa Rahn memiliki pengaruh positif yang signifikan terhadap Kualitas Pelayanan Dalam penelitian ini peneliti belum menemukan penelitian terdahulu yang membahas masalah yang sama sehingga mampu dijadikan keterbaruan pada penelitian.

\section{Pengaruh Nilai-nilai Islam terhadap Kualitas Pelayanan}

Berdasarkan hasil dari uji hipotesis, dapat membuktikan tidak ada pengaruh antara Nilai-nilai Islam BPR Syariah Lantabur Tebuireng terhadap Kualitas Pelayanan. Pengaruh yang dihasilkan adalah positif, yang apabila BPR Syariah Lantabur Tebuireng Cabang Gresik memiliki Nilai-nilai Islam yang semakin tinggi maka akan berdampak pada Kualitas Pelayanan yang semakin besar.

Selain itu dapat dilihat dari nilai t-statistik dan Original Sample $(O)$. Bahwa nilai t-statistik menunjukkan sebesar 1.645305 lebih kecil dari 1,96 dan Original Sample (O) 0.146768. Dengan demikian dapat disimpulkan bahwa Nilai-nilai Islam memiliki pengaruh positif dan tidak signifikan terhadap Kualitas Pelayanan. Sebagai contoh, apabila BPR Syariah Lantabur Tebuireng Cabang Gresik memiliki 
Nilai-nilai Islam, maka masyarakat akan lebih memilih untuk menggunakan jasa yang ditawarkan, dikarenakan Nilai-nilai Islam mengandung unsur-unsur seperti Al-Musawah, Al-'adalah, Al-Ridha, Ash-Shidq dan Al-Kitabah. Dengan begitu akan meningkatkan Kualitas Pelayanan BPR Syariah Lantabur Tebuireng Cabang Gresik. Dalam penelitian ini peneliti belum menemukan penelitian terdahulu yang membahas masalah yang sama sehingga mampu dijadikan keterbaruan pada penelitian.

\section{Pengaruh Kualitas Pelayanan terhadap Kepuasan Nasabah}

Berdasarkan hasil dari uji hipotesis, membuktikan bahwa Kualitas Pelayanan berpengaruh poitif dan signifikan terhadap Kepuasan Nasabah BPR Syariah Lantabur Tebuireng Cabang Gresik.

Hal ini dapat dilihat dari nilai t-statistik dan Original Sample (O). Bahwa nilai t-statistik yang menunjukkan nilai sebesar 2.684771 lebih besar dari 1,96 dan Original Sampel (O) sebesar 0.338881. Dengan demikian dapat disimpulkan bahwa Kualitas Pelayanan memiliki pengaruh positif yang signifikan terhadap Kepuasan Nasabah. Sebagai contoh, apabila Kualitas Pelayanan dalam melayani nasabah dengan cara menyampaikan produk dengan cepat, tepat dan ramah dapat diapahami oleh nasabah maka nasabah akan lebih mengenal dan tertarik untuk melakukan pembiayaan ataupun transaksi keuangan pada BPR Syariah Lantabur Tebuireng Cabang Gresik. Sehingga BPR Syariah Lantabur Tebuireng Cabang Gresik mampu memperoleh pasar yang lebih luas dan meningkatkan Kepuasan Nasabh termasuk total penghimpunan dana, penyaluran dana dan transaksi jasa lainnya.

Berdasarkan hasil penemuan dari penelitian ini di dukung oleh penelitian terdahulu yang dilakukan oleh Intan Kamila, dengan judul Pengaruh Kualitas Produk Dan Kualitas Pelayanan Terhadap Kepuasan Nasabah (Studi Kasus Pada Bank Syariah Mandiri Cabang Jakarta Simprug) Penelitian tersebut menunjukkan bahwa Kualitas Pelayanan berpengaruh secara signifikan terhadap Kepuasan Nasabah. ${ }^{14}$

\footnotetext{
${ }^{14}$ Intan Kamila, "Pengaruh Kualitas Produk Dan Kualitas Pelayanan Terhadap Kepuasan Nasabah (Studi Kasus Pada Bank Syariah Mandiri Cabang Jakarta Simprug) Jakarta”, 2017.
} 


\section{Pengaruh Pembiayaan Murabahah terhadap Kepuasan Nasabah}

Berdasarkan hasil uji hipotesis, Pengaruh pembiayaan Murabahah terhadap Kepuasan Nasabah berdasarkan indikator-indikatornya menunjukkan hasil yang tidak signifikan. Selain itu dapat dilihat dari nilai t-statistik dan Original Smaple (O). Bahwa nilai t-statistik yang menunjukkan nilai sebesar 0.117953 dan nilai ini lebih lebih kecil dari angka 1,96 dan nilai Original Sampel (O) sebesar -0.020375. Dengan demikian dapat disimpulkan bahwa Pembiayaan Murabahah memiliki pengaruh negative tidak signifikan terhadap Kepuasan Nasabah Berdasarkan hasil penelitian ini belum ada ditemukan penelitian terdahulu sehingga bisa di jadikan sebagai keterbaruan dalam penelitian ini.

\section{Pengaruh Rahn Terhadap Kepuasan Nasabah}

Berdasarkan hasil uji hipotesis, Pengaruh Rahn terhadap Kepuasan Nasabah berdasarkan indikator-indikatornya menunjukkan hasil yang signifikan. Selain itu dapat dilihat dari nilai t-statistik dan Original Smaple $(\mathrm{O})$. Bahwa nilai t-statistik yang menunjukkan nilai sebesar 3.003863 lebih besar dari 1,96 dan nilai Original Sampel (O) sebesar 0.436657. Dengan demikian dapat disimpulkan bahwa Rahn memiliki pengaruh positif signifikan signifikan terhadap Kepuasan Nasabah.

Berdasarkan hasil penemuan dari penelitian ini di dukung oleh penelitian terdahulu yang dilakukan oleh Depi Riski Amelia, yaitu Pengaruh Pembiayaan Rahn Terhadap Tingkat Kepuasan Nasabah Pada Pegadaian Syariah (Studi Kasus Pada Pegadaian Syariah Way Halim Bandar Lampung) Penelitian tersebut menunjukkan bahwa Rahn berpengaruh positif dan signifikan terhadap Kepuasan Nasabah. ${ }^{15}$

\section{Pengaruh Nilai-nilai Islam Terhadap Kepuasan Nasabah}

Berdasarkan hasil uji hipotesis, Pengaruh Nilai-nilai Islam terhadap Kepuasan Nasabah berdasarkan indikator-indikatornya menunjukkan hasil yang

\footnotetext{
15 Depi Riski Amelia, "Pengaruh Pembiayaan Rahn Terhadap Tingkat Kepuasan Nasabah Pada Pegadaian Syariah”, Lampung, 2018
} 
tidak signifikan. Selain itu dapat dilihat dari nilai t-statistik dan Original Smaple (O). Bahwa nilai t-statistik yang menunjukkan nilai sebesar 1.334395 lebih kecil dari 1,96 dan nilai Original Sampel (O) sebesar -0.237006. Dengan demikian dapat disimpulkan bahwa Nilai-nilai Islam memiliki pengaruh negative tidak signifikan terhadap Kepuasan Nasabah. Berdasarkan hasil penelitian ini belum ada ditemukan penelitian terdahulu sehingga bisa di jadikan sebagai keterbaruan dalam penelitian ini.

\section{Kesimpulan}

Berdasarkan hasil pembahasan analisis dan pembuktian terhadap Analisi Keunggulan Produk Pembiayaan Murabahah, Rahn dan Nilai-Nilai Islam dengan Kualitas Pelayanan terhadap Kepuasan Nasabah pada Bank Syariah (PT BPR Syariah Lantabur Tebuireng Cabang Gresik) yang telah dijelaskan, dapat ditarik beberapa kesimpulan bahwa hasil pengujian dari variabel Pembiayaan Murabahah terhadap Kualitas Pelayanan berpengaruh positif signifikan kepada PT BPR Syariah Lantabur Tebuireng Cabang Gresik. Hasil pengujian dari variabel Rahn terhadap Kualitas Pembiayaan berpengaruh positif signifikan terhadap PT BPR Syariah Lantabur Tebuireng Cabang Gresik. Hasil pengujian dari variabel Nilai-nilai Islam terhadap Kualitas Pelayanan berdasarkan hasil dari indikatornya menunjukkan hasil yang positif tidak signifikan. Hasil pengujian variabel Kualitas Pelayanan terhadap Kepuasan Nasabah berdasarkan indikator-indikatornya menunjukkan hasil yang positif signifikan. Hasil pengujian variabel Pembiayaan Murabahah terhadap Kepuasan Nasabah berdasarkan indikator-indikatornya menunjukkan hasil negatif tidak signifikan. Hasil pengujian variabel Rahn terhadap Kepuasan Nasabah berdasarkan indikator-indikatornya menunjukkan hasil positif signifikan. Hasil pengujian variabel Nilai-nilai Islam terhadap Kepuasan Nasabah berdasarkan indikator-indikatornya menunjukkan hasil negatif tidak signifikan.

Berdasarkan hasil penelitian, pembahasan, serta kesimpulan yang telah di kemukakan, berikut ini adalah beberapa saran: 1) Disarankan bagi nasabah maupun calon nasabah yang akan menabung maupun berinvestasi pada suatu perusahaan ataupun pada bank sebaiknya melihat dulu kondisi dari perusahaan atau bank yang akan dipilih. Dalam hal ini nasabah melihat kesehatan atau kondisi keuangan 
perusahaan maupun bank dalam laporan keuangan perusahaan. Dari laporan keuangan tersebut dapat dilihat dari nilai perkembangan perusahaan setiap tahunya sehingga nasabah dapat menempatkan dana atau modalnya pada Perbankan Syariah yang tepat; 2) Disarankan bagi peneliti selanjutnya yang akan membahas topik yang sama dengan penelitian ini, maka disarankan untuk menambah atau memperbanyak variabel ataupun indikatornya. Yang akan memperbanyak variasi dalam menentukan beberapa faktor yang akan mempengaruhi terhadap risiko kebangkrutan pada Perbankan Syariah bersangkutan.

\section{Daftar Pustaka}

Abdullah, Hafid. Kunci Fiqih Syafi'i. Semarang: CV As-syifa', 1992.

Abidin, Muhammad. "Pengaruh Kualitas Pelayanan Terhadap Tingkat Kepuasan Nasabah (Studi Kasus Pada Bank Syariah Mandiri Cabang Magelang), Yogyakarta, 2010

Aisiyah, Binti Nur. Manajemen Pembiayaan Bank Syariah, Yogyakarta: Kalimedia, 2015.

Amelia, Depi Riski. "Pengaruh Pembiayaan Rahn Terhadap Tingkat Kepuasan Nasabah Pada Pegadaian Syariah”, Lampung, 2018

Amir, Muhammad Nur Fauzi. Pengaruh Nilai Pelanggan, Kepuasan Nasabah, Kualitas Pelayanan Dan Relationship Marketing Terhadap Loyalitas Nasabah, Jakarta: 201).

Antonio, M. Syaf 'i. Bank Syariah dari Teori ke Praktek. Jakarta: Gema Insani. 2001

Antonio, M. Syafi'i. Bank Syariah Analisis kekuatan, Kelemahan, peluang dan Ancaman, cet. III. Yogyakarta: Ekonisia, 2004

Ashraf, Thariq. "Sharia-complaint Investing: Concept and Opportunities", http://www.csri.orgnz/document/tashraf, diakses tanggal 5 April 2019

Az Zuhaili, Wahbah. Al Fiqh Al Islami wa Adillatuhu, Damascus: Dar al-Fikr,1997. Azizah, Nur., Purnomo, Joko Hadi., Hidayati, Niswatin Nurul. "Efektivitas Strategi Pemasaran Produk Tabungan Haji Dalam Meningkatkan Keunggulan Kompetitif di BRI Syariah Kantor Cabang Pembantu Bojonegoro". MIYAH: Jurnal Studi Islam. 16(1). 2020, 135-161.

Depag RI, Al-Qur'an dan Terjemahnya, Jakarta : Bumi Restu, 1974

Ensiklopedi Fiqh online, diakses dari www.fikihonline.com

Haryanti, Nik., dan Baqi, Diyanus Abdul. "Strategi Service Quality Sebagai Media dalam Menciptakan Kepuasan dan Loyalitas Pelanggan”. Journal of Sharia Economics. 1(2). 2019, 101-128

Hendry, Arrison Perbankan Syariah, Jakarta: Muamalah Institute, 1999.

Hermanto, "Pengaruh Kualitas Pelayanan SDM Bank Syariah Terhadap Kepuasan Nasabah (Studi Pada Bprs Berkah Ramadhan)". 2013.

Irmawati, Elli. "Analisis Pengaruh Pembiayaan Mudharabah, Musyarakah, Murabahah, Dan Multijasa Terhadap Profitabilitas PT BPRS Lantabtur Tebuireng Periode 2010-2017”, Malang: 2018 
Juliandi, Azwar. Modul pelatihan: Structural Equation Model partial least square (SEM-PLS) dengan SMARTPLS, Program Studi Administrasi Bisnis: Universitas Sumatera Utara 2018.

Kamila, Intan. "Pengaruh Kualitas Produk Dan Kualitas Pelayanan Terhadap Kepuasan Nasabah (Studi Kasus Pada Bank Syariah Mandiri Cabang Jakarta Simprug) Jakarta", 2017.

Lupiyoadi, Rambat. Manajemen Pemasaran Jasa, Jakarta: Salemba Empat, 2013.

Mar'ah, Ana Kholifatul., Purnomo, Joko Hadi., Hidayati, Niswatin Nurul. "Effect of Mudharabah Financing Toward Seller Members' Income at BMT Usaha Artha Sejahtera Bojonegoro. SHAHIH: Journal of Islamicate Multidisciplinary. 5(1). 2020, 15-36.

Meyandi, Hery. "Analisis Pengaruh Pengungkapan Syariah Compliance Dalam Meningkatkan Kepuasan Nasabah (Studi Pada Bank Pembiayaan Rakyat Syariah Bandar Lampung)", Lampung, 2018

Muctharom, Moch Zaenal Azis "Pengaruh Kualitas Produk Murabahah, Harga, dan Kualitas Pelayanan Terhadap Kepuasan Nasabah di Baitul Maal Wat Tamwil Nurul Ummah Ngasem Bojonegoro". Journal of Sharia Economics. 1(1). 2019, 41-54

Muhammad, Manajemen Dana Bank Syariah, Jakarta: Rajawali Pers, 2014.

Munawaroh, "Penerapan Nilai-Nilai Islam Pada Bank Syariah Dan Pengaruhnya Terhadap Loyalitas Nasabah (Studi Kasus Pada Masyarakat Kota Medan”. Medan, 2016

Munawwir, Ahmad Warson. Al-Munawwir, Kamus Arab-Indonesia, Cet. IV, Surabaya: Pustaka Progressif, 1997

Muttaqien, Dadan. Aspek Legal Lembaga Keuangan Syari'ah, cet 1, Yogyakarta: Safira Insani Press, 2009

Ni'mah, Karomatun., Purnomo, Joko Hadi., Hidayati, Niswatin Nurul. "Pengaruh Marketing, Nilai Taksiran, Dan Biaya Titip Pada Gadai Emas Terhadap Minat Nasabah Menggunakan Fasilitas Gadai Emas di PT. Bank Syariah Mandiri KCP Tuban”. LISAN AL-HAL: Jurnal Pengembangan Pemikiran dan Kebudayaan. 14(1). 2020, 1-38.

Otoritas Jasa Keuangan (OJK), Statistik Perbankan ... ..diakses tanggal 5 April 2016

Pasal 24 ayat (1) dan ayat (2) huruf a dan Pasal 25 huruf a Undang-Undang No. 21

Tahun 2008 tentang Perbankan Syariah. 2018

Purnomo, Joko Hadi. “Uang dan Moneter dalam Sistem Keuangan Islam”. Journal of Sharia Economics. 1(2). 2019. 80-100.

Ridwan, Muhammd. Konstruksi Bank Syariah di Indonesia, Yogyakarta: Pustaka SM, 2007.

Roni, Mukhamad. 'Pengaruh Religiusitas, Kepemimpinan, Etos Kerja, Kepuasan Kerja Dan Kompensasi Terhadap Kinerja Karyawan Dengan Motivasi Sebagai Variabel Intervening", (Surabaya: Universitas Islam Negeri Sunan Ampel Suarabaya, 2019 Tesis.

Rusyd, Ibnu. Bidayatul Mujtahid wa Nihayatul Mugtashid, Beirut Lebanon: Dar alKutub Al-Ilmiyah.

Sabiq, Sayyid. Fiqih Sunnah, Jakarta: Pena Pundi Aksara, 2006

Setiawan, Heri., Minarsih, Maria Magdalena., dan Fathoni, Azis. "Pengaruh Kualitas Produk, Kualitas Pelayanan, Dan Kepercayaan terhadap Kepuasan Nasabah Dan Loyalitas Nasabah Dengan Kepuasan Sebagai Variabel 
Intervening (Studi Kasus Pada Nasabah Koperasi Rejo Agung Sukses Cabang Ngaliyan". Semarang: 2016

Sholihin, Ahmad Ifham. Buku Pintar Ekonomi Syariah, Jakarta: Gramedia Pustaka Utama, 2010.

Sjahdeini, Sutan Remy. Perbankan Syariah, Produk-produk dan Aspek-aspek Hukumnya, Jakarta: Kencana Prenada Media Group, 2014

Sugiyono, Metode Penelitian Kuantitatif, kualitatif, dan R\&D, Bandung: Alfabeta, 2016.

Sugiyono, Metode Penilitian, Bandung: Alfabeta, 2017

Suherly. "Pengaruh Kualitas Pelayanan Dan Kepuasan Nasabah Terhadap Loyalitas Nasabah Di Bank Bni Syariah Cabang Cirebon," Cirebon, 2013.

Supranto, J. "Pengukuran Tingkat Kepuasan Pelanggan Untuk Menaikkan Pangsa Pasar”. cet. III, Jakarta: Rineka Cipta, 2006. 